\title{
Effect of Y Content on Properties of Extruded Zn-1.5Mg-xY Alloys for Medical Applications
}

\author{
Yajing Zhang ${ }^{a}{ }^{\oplus}, Q_{i} L^{a}{ }^{a}$, Tingting Guo ${ }^{a}$, Shuaiping $L^{a}$ \\ ${ }^{a}$ School of Materials Science \& Engineering, Northeastern University, Shenyang, 110819, China
}

Received: January 03, 2019; Revised: March 19, 2019; Accepted: April 30, 2019

\begin{abstract}
In this work, we investigated the effect of $y \operatorname{ttrium}(\mathrm{Y})$ on microstructure, the mechanical and corrosion properties and the cytotoxicity of $\mathrm{Zn}-1.5 \mathrm{Mg}-\mathrm{xY}(\mathrm{x}=0,0.2,0.5 \mathrm{wt} \%)$ alloys prepared by casting and extrusion. The results showed that the microstructure of extruded $\mathrm{Zn}-1.5 \mathrm{Mg}$-xY alloys consisted of $\alpha-\mathrm{Zn}$ matrix, $\mathrm{Mg}_{2} \mathrm{Zn}_{11}$ particles and $\mathrm{Y}$ containing blocks. The tensile strength and compressive strength of $\mathrm{Zn}-1.5 \mathrm{Mg}-\mathrm{xY}$ alloys improve with the increase of $\mathrm{Y}$ content. Alloying with $\mathrm{Y}$ also had an impact on the corrosion resistance of $\mathrm{Zn}-\mathrm{Mg}$ alloys. In terms of toxicity, the cells cultured in the leachate of $\mathrm{Zn}-1.5 \mathrm{Mg}-\mathrm{xY}$ alloys with concentrations of $25 \%$ and $50 \%$ showed good growth morphology with the relative proliferation rate (RGR) values being greater than $100 \%$ and the cytotoxicity level being 0 , the addition of $Y$ has little effect on the compatibility of alloy with cells.
\end{abstract}

Keywords: Zinc alloys, vitro corrosion, cytotoxicity, mechanical properties, corrosion resistance.

\section{Introduction}

Metallic biomaterials, such as stainless steel, titanium alloys and Fe-based alloys are widely used in making loadbearing medical implants. ${ }^{1}$ With the development of new materials and technologies, in order to providing implants with higher clinical performance, $\mathrm{Zn}$-based alloys have been investigated as candidates for the fabrication of biodegradable implants such as intravascular stent or bone scaffold.

The standard electropotential of $\mathrm{Zn}$ is $-0.76 \mathrm{~V}$, which is between those of $\mathrm{Mg}(-2.37 \mathrm{~V})$ and $\mathrm{Fe}(-0.44 \mathrm{~V})$. In the perspective of corrosion resistance, $\mathrm{Zn}$ and $\mathrm{Zn}$ alloys are expected to show an appropriate degradation rate. ${ }^{2}$ Besides, $\mathrm{Zn}$ is an essential trace element in human body, playing important roles in many biological processes in human organisms, and meet the safety requirement for biomedical use. ${ }^{3-5}$ Bowen et al. ${ }^{6}$ placed pure $\mathrm{Zn}$ wires into the arteries of rats and they degraded at a rate just below $0.2 \mathrm{~mm}$ per year - the "magic" value for bio-absorbable stent-for the first three months. After that, the corrosion accelerated, so the implant would not remain in the artery for too long. However, $\mathrm{Zn}$ alloy still suffer from the problem of low mechanical properties. In order to overcome the problem of low strength and low hardness of pure zinc, adding alloying elements would be an appropriate way to adjust microstructure and mechanical prperties.

Magnesium is essential to human metabolism, it can be easily degraded and absorbed, and its mechanical properties are similar to those of natural bone. ${ }^{7} \mathrm{Xiao}^{8}$ conducted in vitro and in vivo studies on a $\mathrm{Zn}-0.05 \mathrm{wt} \% \mathrm{Mg}$ alloy with pure $\mathrm{Zn}$ as a control. The results clearly demonstrated that the $\mathrm{Zn}-0.05 \mathrm{Mg}$ alloy could be a potential biodegradable orthopedic implant material. $\mathrm{Y}$ is an element that the bodycan metabolize, and the addition of $Y$ can refine the grain and improve the mechanical properties of Mg alloys. ${ }^{9-12}$
$Z_{\text {hao }}{ }^{13}$ investigated the effect of $\mathrm{Y}$ on microstructure and mechanical properties of as-cast Mg-8Li-3Al-2Zn (wt\%) alloy. The results showed that the grains of the as-cast $\mathrm{Mg}$ 8Li-3Al-2Zn (wt\%) alloy were refined dramatically with the addition of $\mathrm{Y}$.

This study took $\mathrm{Mg}$ and $\mathrm{Y}$ as alloying elements, and prepared $\mathrm{Zn}-1.5 \mathrm{Mg}-\mathrm{xY}$ alloys by casting and indirect extrusion. The microstructure, mechanical and corrosion behavior, and the in vitro cytocompatibility of the prepared materials were investigated in detail.

\section{Materials and Methods}

$\mathrm{Zn}-1.5 \mathrm{Mg}-\mathrm{xY}$ alloy ingots were prepared by melting commercially pure $\mathrm{Zn}$ (purity: $99.99 \mathrm{wt} \%$ ) and $\mathrm{Mg}-35 \mathrm{Y}$ $(w t \%)$ master alloy. After casting, indirect extrusion of the ingots was performed to produce rods of $12 \mathrm{~mm}$ in diameter. The compositions of the alloys are shown in Table 1 . The metallography surfaces of the alloy samples were etched with a solution of $4 \%$ (volume fraction) nitric acid and ethyl alcohol. Phase identification was carried out via X-ray diffraction (XRD) using RIGAKU-3014 X-ray analyzer. The OLTMPUS GX51 metalloscope and Hitachi S-4800 scanning electron microscope(SEM) equipped with energy-dispersive X-ray spectrometer (EDS) were used to analyze the microstructure. Corrosion resistance tests, including impedance measurement and potentiodynamic polarization measurement, were carried out in simulated body fluid (SBF). The electrochemical property of the alloys was tested in CHI660E electrochemical testing system at $37^{\circ} \mathrm{C}$ with saturated calomel electrode (SCE) as the reference electrode and graphite as the counter electrode. The scanning rate was $0.5 \mathrm{mV} / \mathrm{s}$. 
Table 1. The nominal chemical compositions of $\mathrm{Zn}-1.5 \mathrm{Mg}-\mathrm{xY}$ alloys in $\mathrm{wt} \%$

\begin{tabular}{cccc}
\hline & $\mathrm{Mg}$ & $\mathrm{Y}$ & $\mathrm{Zn}$ \\
\hline 1 & 1.5 & 0 & Balance \\
2 & 1.5 & 0.2 & Balance \\
3 & 1.5 & 0.5 & Balance \\
\hline
\end{tabular}

MC3T3 cells were also used to assess the in vitro cytotoxicity of the extract media prepared by immersing the specimens in culture media. Modified Eagle's medium alpha ( $\alpha$-MEM) was used as control group culture medium. Before extracting the culture solution, the specimens were processed into $\varphi 10 \times 4 \mathrm{~mm}$ and polished to match the surface finish required in live/dead direct cell viability testing. The ratio of culture media surface area to specimen weight was maintained at $1.25 \mathrm{~cm}^{2}$ to $1 \mathrm{~mL}$. For this analysis, $100 \%$ extract was then further diluted to $50 \%$ and $25 \%$ extract solutions. The absorbance of light was measured by enzyme marker at a wave length of $570 \mathrm{~nm}$.

\section{Results and Discussion}

Phase identification by using XRD in Fig. 1 shows that $\alpha-\mathrm{Zn}$ and $\mathrm{Mg}_{2} \mathrm{Zn}_{11}$ are dominant phases in the samples. $\mathrm{Mg}_{2} \mathrm{Zn}_{11}$ phase is intermetallic compound phase, which is hard and brittle. The yttrium containing phase is undetected by XRD, because of its low content (under $0.5 \%$ ) and the low sensitivity of the device.

Fig. 2 is the SEM backscattered electorn image and the EDS elemental map of the microstructure of $\mathrm{Zn}-1.5 \mathrm{Mg}$ $0.5 \mathrm{Y}$ alloy. The pink areas in Fig. 2(b) represent yttrium containing particles, while the green areas in Fig. 2(b) represents magnesium containing particles. Based on the XRD analysis, SEM examination and EDS analysis, the microstructure of the $\mathrm{Zn}-1.5 \mathrm{Mg}-0.5 \mathrm{Y}$ alloy consists of $\alpha$-Zn matrix, $\mathrm{Mg}_{2} \mathrm{Zn}_{11}$ particles and block-like $\mathrm{Y}$ containing particles.

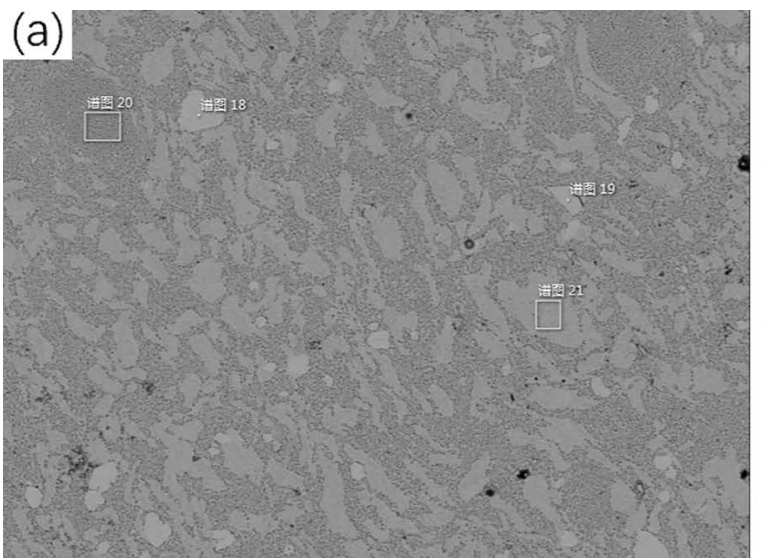

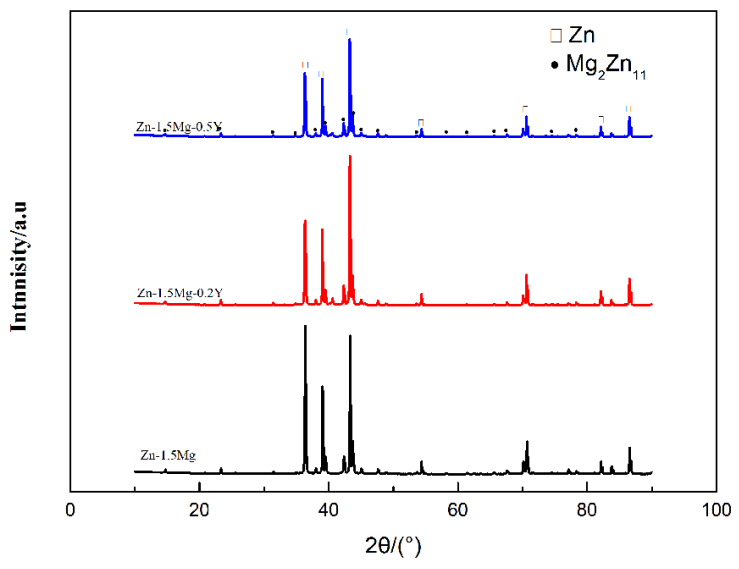

Figure 1. The XRD patterns of $\mathrm{Zn}-1.5 \mathrm{Mg}-\mathrm{xY}$ alloys.

As shown in Fig. 3, the microstructure of the three samples all consisted of equiaxed grain, and twinning took place in some phase field (the circled part in Fig. 3(d-e)). There is no sign of deformation in the form of elongated shape of the structural feature. This means that dynamic recrystallization took place during the extrusion process, and in the mean time, as the slip resistance increased with increasing the amount of extrusion deformation, twinning occurred. According to Clark $^{14}$, the secondary phase particles could nucleate along the dislocation lines and pin the dislocation slip at their initial state, which is favorable for twinning. This is consistent with the results of the experiment. According to Fig. 3, we found that with the addition of yttrium, the second phase particles were distributed more uniformly, but in the meantime, they were coarser.

In the case of the $\mathrm{Zn}-\mathrm{Mg}$ alloy, $\mathrm{Mg}$ is dissolved in the $\mathrm{Zn}$ matrix, when the content of $\mathrm{Mg}$ is higher than $0.5 \%$, numerous $\mathrm{Mg}_{2} \mathrm{Zn}_{11}$ secondary phase particles precipitated out and existed in the microstructure. Eutectic structure also form during the solidification of the alloy, primary $\alpha-Z n$ crystals nucleate and grow, the $\mathrm{Y}$ content in the liquid phase increases, and the yttrium-rich phase is easy to form. ${ }^{15}$

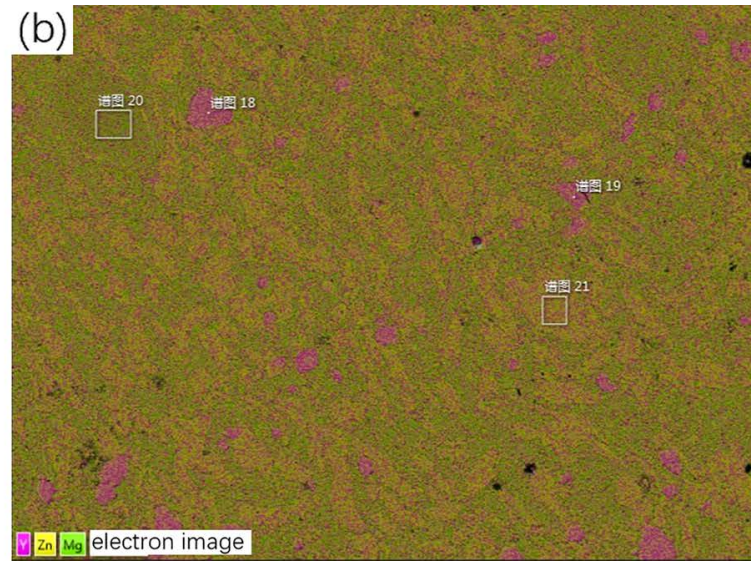

Figure 2. (a) SEM backscaterred electron image and, (b) EDS elemental map of the microstructure of Zn-1.5Mg- $0.5 \mathrm{Y}$ alloy. 

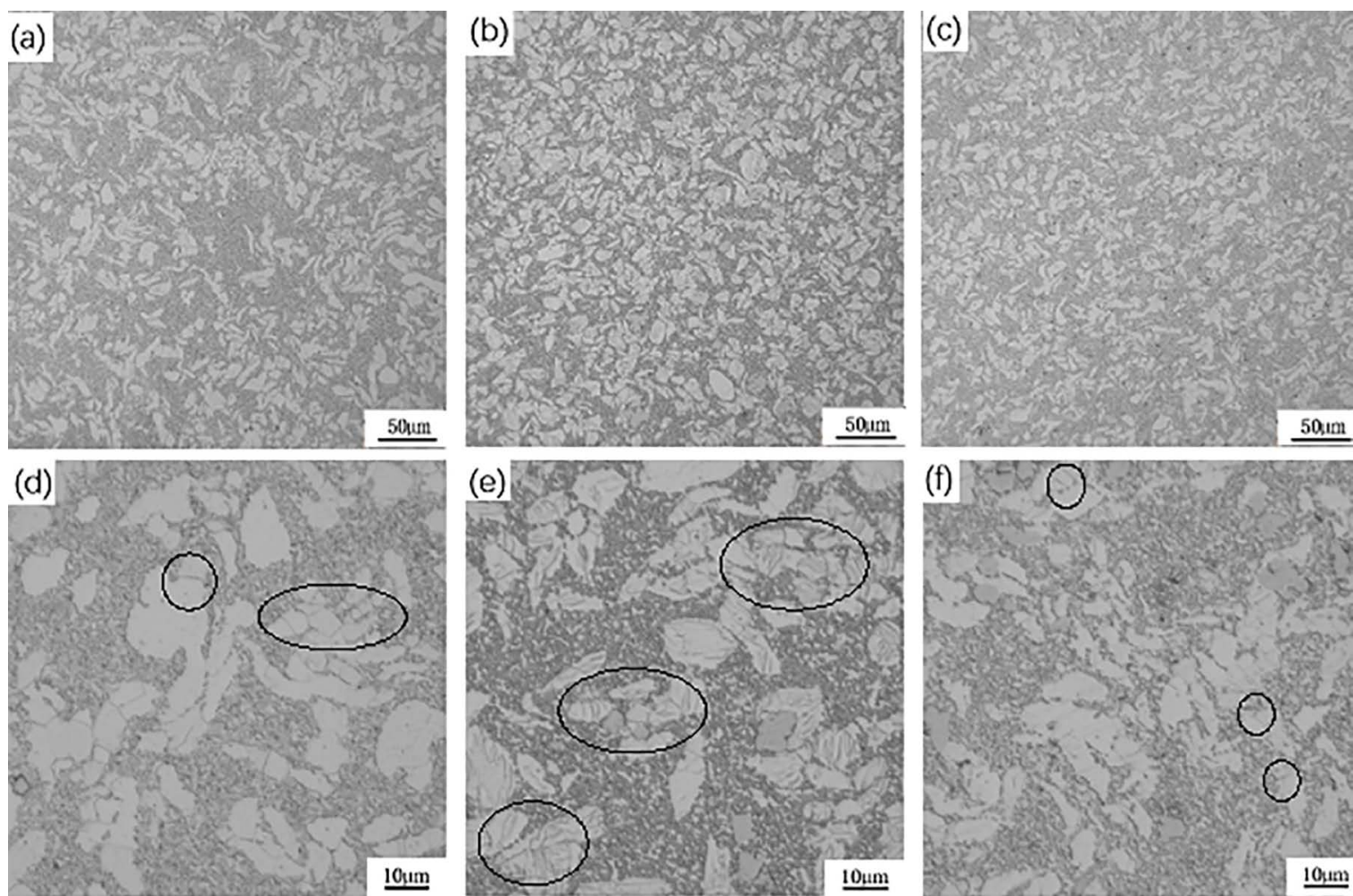

Figure 3. The microstructure of the $\mathrm{Zn}-1.5 \mathrm{Mg}-\mathrm{xY}$ alloys (a) (d) $-\mathrm{Zn}-1.5 \mathrm{Mg}$ alloy, (b) (e) $-\mathrm{Zn}-1.5 \mathrm{Mg}-0.2 \mathrm{Y}$ alloy, (c) (f) $-\mathrm{Zn}-1.5 \mathrm{Mg}-0.5 \mathrm{Y}$ alloy

During the solidification process of the alloy, the solute atom $\mathrm{Y}$ is pushed to the solid-liquid front, which increases the constitutional undercooling of the solid-liquid front and impedes the grain growth. This also leads to the formation of the brittle phase containing $\mathrm{Y}$ at the grain boundary and further hinders the grain growth. ${ }^{16-18}$ However, in this study, the grain size increases with the increased of $\mathrm{Y}$ element, and the distribution of yttrium phase at the grain boundary was not significant. The reason could be that the effect of refining grain size by RE element decreased with increasing temperature during homogenized process, which was used to eliminate grain boundary segregation ${ }^{18}$. The specific reasons need to be further studied.

Mechanical property is the major property for biodegradable metal implant material. After implantation, implantation device should play a certain role of fixed support, so it should have enough mechanical properties. ${ }^{19}$ The mechanical properties of implantable materials are also different under different service conditions. The yield strength of degradable bone fixation should be greater than $200 \mathrm{MPa}$ at room temperature. ${ }^{20}$ The mechanical properties of cardiovascular scaffolds should meet the yield strength greater than 200 $\mathrm{MPa}$ and tensile strength greater than $300 \mathrm{MPa} .{ }^{6}$ The strength of extension, yield strength and compressive strength of as-extruded $\mathrm{Zn}-1.5 \mathrm{Mg}$-xY alloys are shown in Table 2 .
Table 2. The strength changes of $\mathrm{Zn}-1.5 \mathrm{Mg}-\mathrm{xY}$ alloys with different $\mathrm{Y}$ content

\begin{tabular}{llll}
\hline \multicolumn{1}{c}{ Y/\% } & 0.0 & 0.2 & 0.5 \\
\hline Yield strength /MPa & 418 & 423 & 447 \\
Tensile strength/MPa & 430 & 455 & 469 \\
Compressive strength/MPa & 354 & 366 & 430 \\
\hline
\end{tabular}

The mechanical properties of the alloys all meet the requirements. Yield strength, tensile strength and compressive strength increase with increasing $\mathrm{Y}$ content, which may be because the Y-containing phase broke during extrusion, its distribution was finer and more uniform, the bond with the matrix was tighter, and it had a stronger hindering effect on the movement of dislocations ${ }^{16}$.

Potentiodynamic polarization curves were used to explain the differences of corrosion behavior of the $\mathrm{Zn}-1.5 \mathrm{Mg}-\mathrm{xY}$ alloys. The obtained potentiodynamic curves are plotted in Fig. 4. The shapes of the potentiodynamic curves were basically similar. The stable stages of the anode polarization curves are not much different, but the corrosion potential of $\mathrm{Zn}-1.5 \mathrm{Mg}$ $0.2 \mathrm{Y}$ and $\mathrm{Zn}-1.5 \mathrm{Mg}-0.5 \mathrm{Y}$ alloys are higher. The corrosion potential of the three samples are $-1.091 \mathrm{~V},-1.035 \mathrm{~V}$ and $-1.061 \mathrm{~V}$ respectively, and the corrosion current densities are $1.35 \times 10^{-5}$ $\mathrm{A} \cdot \mathrm{cm}^{-2}, 8.91 \times 10^{-6} \mathrm{~A} \cdot \mathrm{cm}^{-2}$ and $1.26 \times 10^{-5} \mathrm{~A} \cdot \mathrm{cm}^{-2}$ respectively. 


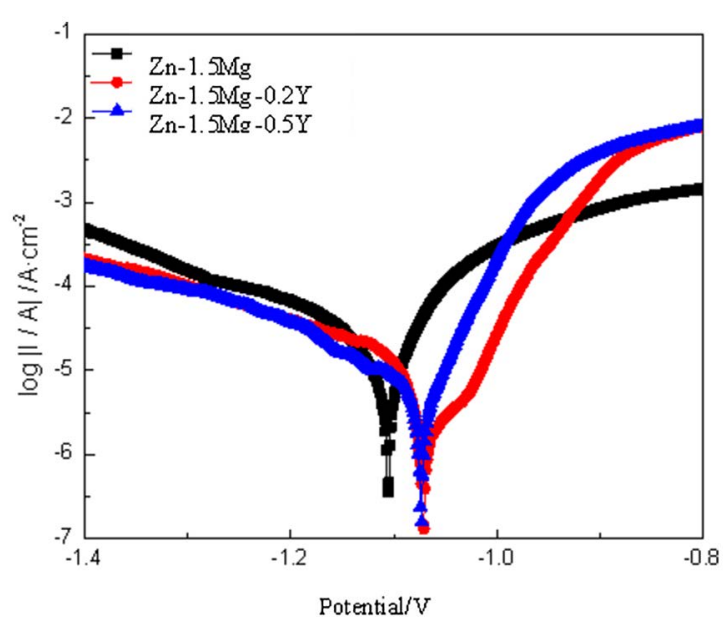

Figure 4. The polarization curves of $\mathrm{Zn}-1.5 \mathrm{Mg}-\mathrm{xY}$ alloy samples in the SBF solution.

The corrosion rate of alloy was calculated by corrosion current density. The corrosion rates of the three samples are $0.21 \mathrm{~mm} / \mathrm{y}, 0.14 \mathrm{~mm} / \mathrm{y}$ and $0.19 \mathrm{~mm} / \mathrm{y}$ respectively.

Figure 5 shows the impedance curves of $\mathrm{Zn}-1.5 \mathrm{Mg}-\mathrm{xY}$ alloy samples in SBF solution $\left(37 \pm 1^{\circ} \mathrm{C}\right)$. Charge transfer resistance and surface film resistance are proportional to capacitance arc diameter of the high-frequency area. Therefore, the size of the capacitance arc represents the degree of difficulty in dissolving the zinc matrix. The corrosion resistances are $110 \Omega, 310 \Omega$ and $160 \Omega$ respectively. The results of corrosion resistance are consistent with the results got from the potentiodynamic polarization curves.

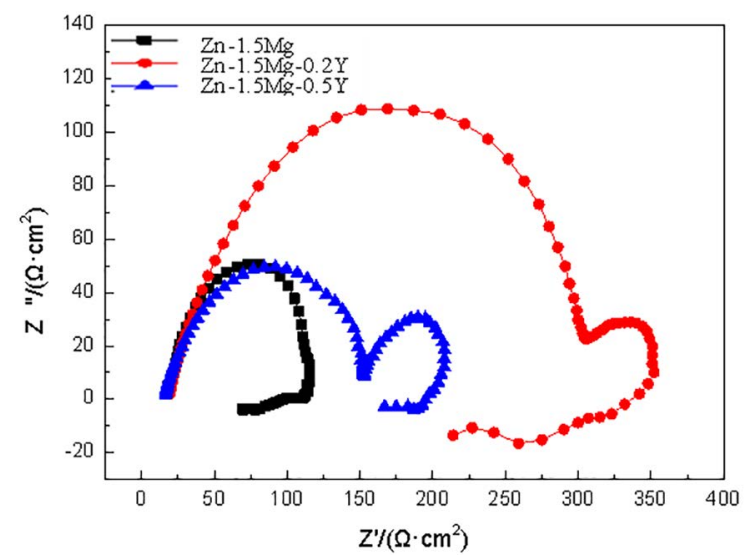

Figure 5. The electrochemical impedance spectroscopys (EIS) plot of $\mathrm{Zn}-1.5 \mathrm{Mg}-\mathrm{xY}$ alloy samples in SBF solution.
The results show that the addition of $\mathrm{Y}$ improves the corrosion resistance of the $\mathrm{Zn}-\mathrm{Mg}$ alloy. With $\mathrm{Y}$ element increasing, the number of brittle phases increased, which may initiate more local corrosion microbattery reaction, thus showing greater corrosion-prone tendency. However, the corrosion resistance of alloy may be affected by grain size and type. According to $\mathrm{Liu}^{21}$, the corrosion resistance of twin samples is better than that of non-twin samples. Twin crystal structures are too active to dissolve in corrosion solution and then rapidly form a surface film covers on the surface layer. This film can protect the material well before it loses efficacy and therefore the corrosion resistance of the alloy is improved.

Table 3 is the results of comparing the relative growth rates (RGR) of mouse osteoblasts after incubation for 3 days in $\mathrm{Zn}-1.5 \mathrm{Mg}$-xY alloy sample extracts at concentrations of $25 \%, 50 \%$ and $100 \%$ respectively. The cytotoxic levels of mouse osteoblasts cultured in the extract of alloys samples are also shown. The proliferation rate cultures in different culture solutions under concentrations of $50 \%$ for 3 days are all over $100 \%$, the cytotoxicity levels are 0 .

The relative productivity rates of cells cultured for 3 days after the leaching solution of three different components of the $\mathrm{Zn}-1.5 \mathrm{Mg}$-xY alloys at $100 \%$ concentration were less than $20 \%$, and the cytotoxicity levels were level 4 . When the concentration of the extract was $100 \%$, the relative productivity rate of the cells was significantly reduced, which could no longer meet the requirements of cytotoxicity as a biomedical material. It showed that the presence of a small amount of zinc, magnesium and yttrium ions in the cell culture medium could promote the growth of mouse osteoblasts, while the excessive concentration of zinc, magnesium and yttrium ions could inhibit cell proliferation and lead to toxicity. Therefore, as a biomaterial, $\mathrm{Zn}-1.5 \mathrm{Mg}-\mathrm{xY}$ alloys need to strictly control the release concentration of alloy ions, which needs to be further studied. The cell morphology of mouse osteoblasts cultured in the extract of alloys samples (concentration was $25 \%, 50 \%$ and $100 \%$ ) for 3 days are shown in Fig. 6. The results show the cells cultured in $25 \%$ and $50 \%$ extracts are in good condition and no dead cells are observed. After 3 days of culture, the cells are almost full of petri dishes. The cultured cells in the three alloy sample extracts with $100 \%$ concentration show the dead state of desiccation and deformity. It is further intuitively demonstrated that the concentration of $100 \% \mathrm{Zn}-1.5 \mathrm{Mg}-\mathrm{xY}$ alloy sample is too high to meet the requirements of cytotoxicity as a biological material.

Table 3. CCK 8 test results of mouse osteoblasts after 3days

\begin{tabular}{lcccccc}
\hline \multirow{2}{*}{ Samples } & \multicolumn{2}{c}{$25 \%$} & & $50 \%$ & \multicolumn{2}{c}{$100 \%$} \\
\cline { 2 - 7 } & RGR/\% & Grade & RGR/\% & Grade & RGR $/ \%$ & Grade \\
\hline Negative control & 100 & 0 & 100 & 0 & 100 & 0 \\
Zn-1.5Mg & 171 & 0 & 150 & 0 & 15 & 4 \\
Zn-1.5Mg-0.2Y & 170 & 0 & 143 & 0 & 14 & 4 \\
Zn-1.5Mg-0.5Y & 164 & 0 & 154 & 0 & 14 & 4 \\
\hline
\end{tabular}




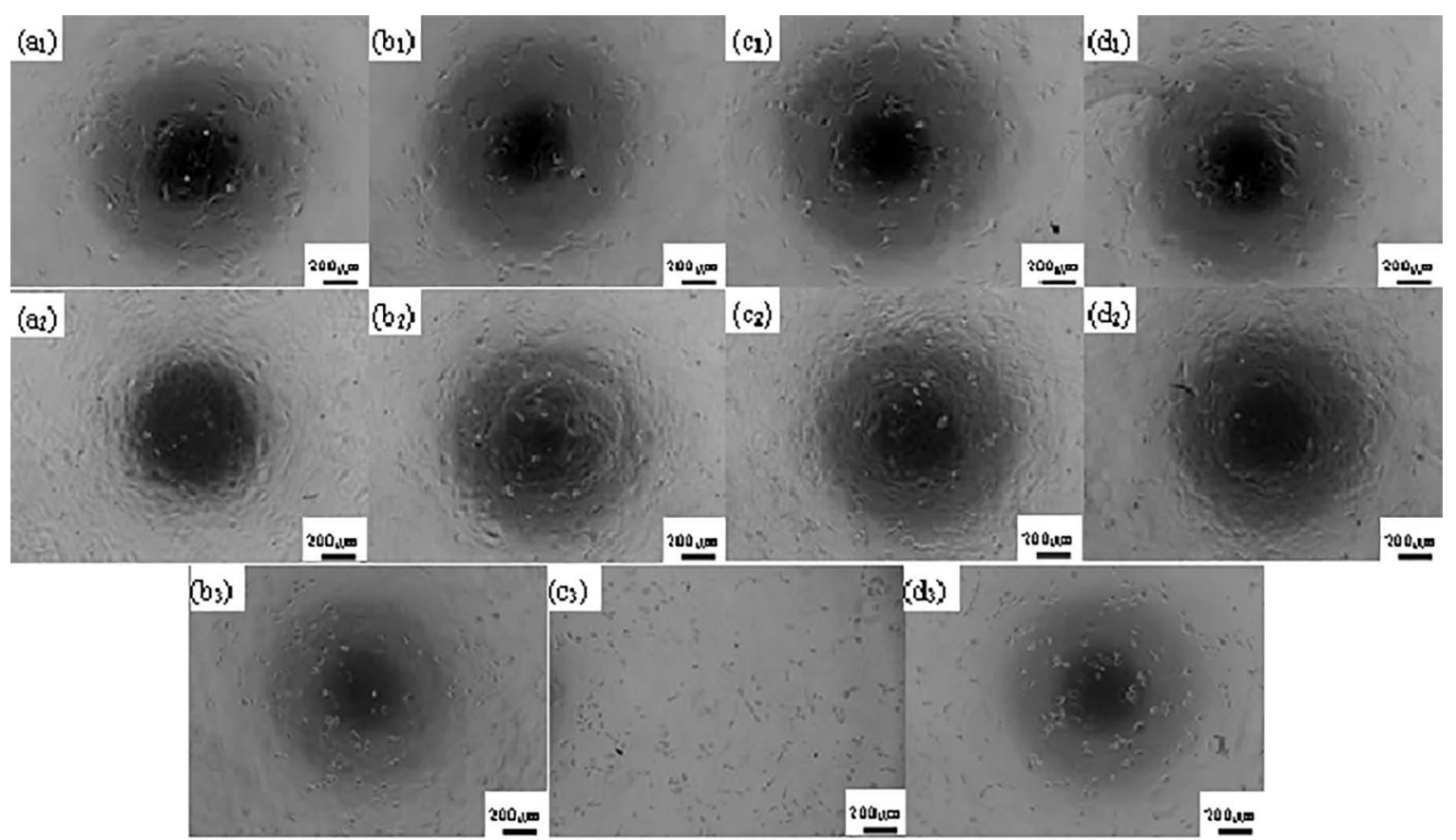

Figure 6. The morphologies of mouse osteoblasts cultured in extraction medium after 0 and 3 days (a) control group, (b) $\mathrm{Zn}-1.5 \mathrm{Mg}$, (c) Zn-1.5Mg-0.2Y, (d) Zn-1.5Mg-0.5Y 1: 0 day; 2: 3 days for $50 \%$ extraction medium; $3: 3$ days for $100 \%$ extraction médium.

It has been widely reported that rare earth elements have important effects on human health. The potential toxic effects of rare earth elements on humans are also the focus of scientific research. Rare earth elements can be transported to tissues and organs through blood, the uptake of rare earth elements by tissues and organs is related to toxicity, species, dosage and organs. ${ }^{22} \mathrm{~A}$ large number of studies have reported that rare earth elements can promote animal growth when doses of rare earth elements are very low, and over a certain dose may produce subchronic or chronic toxic effects, the excessive intake of heavy rare earth elements such as yttrium can lead to liver toxicity and other complications.

In this study, the results show that the concentration of the extract would affect the relative activity of the cells. For mouse osteoblasts, the concentration of the leaching solution has little effect on the activity of the cells. Except mouse osteoblasts cultured in $100 \%$ leaching solution showed low relative activity (RGR\% $<20 \%$ ) and high relatively cytotoxicity level (cytotoxicity level was level 4), the relative activities in other diluted leaching solutions are higher than $100 \%$ and the cytotoxicity levels were level 0 , according to the standard ISO 10993-5. Mouse osteoblasts showed considerable tolerance to dilute $\mathrm{Zn}$ $1.5 \mathrm{Mg}-\mathrm{xY}$ alloy leaches. The present in vitro results demonstrate that the MC3T3-E1 exhibit good growth in low concentration $\mathrm{Zn}-1.5 \mathrm{Mg}-\mathrm{xY}$ alloy extraction mediums. These results also imply good in vitro biocompatibility of the $\mathrm{Zn}-1.5 \mathrm{Mg}-\mathrm{xY}$ alloys.

\section{Conclusions}

In this paper the effects of yttrium on the mechanical property, corrosion behavior, cytotoxicity and cell morphology of Zn-Mg alloys were studied. Key findings of the study are:

(1) The addition of $Y$ increases the yield strength, tensile strength and compressive strength of $\mathrm{Zn}-\mathrm{Mg}$ alloys. The addition of $0.5 \mathrm{wt} \% \mathrm{Y}$ element increases the tensile strength and compressive strength of the alloy by about $30 \mathrm{MPa}$ and $40 \mathrm{MPa}$, the tensile strength and compressive strength are $447.4 \mathrm{Mpa}$ and 469.1 MPa respectively.

(2) The addition of $Y$ has an impact on the corrosion resistance of $\mathrm{Zn}-\mathrm{Mg}$ alloy. The corrosion rates of the $\mathrm{Zn}-1.5 \mathrm{Mg}-\mathrm{xY}(\mathrm{x}=0,0.2,0.5)$ alloys are $0.21 \mathrm{~mm} /$ $\mathrm{y}, 0.14 \mathrm{~mm} / \mathrm{y}$ and $0.19 \mathrm{~mm} / \mathrm{y}$ respectively.

(3) Cells cultured in $25 \%$ and $50 \% \mathrm{Zn}-1.5 \mathrm{Mg}$-xY alloys samples extraction solutions show good growth morphology. The relative proliferation rates of cells are more than $100 \%$, and the cytotoxicity levels are 0 , which meets the cytotoxicity requirements of biological materials.

\section{References}

1. Long M, Rack HJ. Titanium alloys in total joint replacement--a materials science perspective. Biomaterials. 1998;19(18):1621-1639.

2. Gu NJ. Mechanical and Corrosion Resistance Properties of Biodegradable $\mathrm{Zn}-\mathrm{Mg}$ based alloys extruded Indirectly. [Dissertation]. Northeastern University; 2014. (in Chinese) 
3. Gu X, Wang F, Xie X, Zheng M, Li P, Zheng Y, et al. In vitro and in vivo studies on as-extruded Mg-5.25wt.\%Zn-0.6wt.\%Ca alloy as biodegradable metal. Science China Materials. 2018;61(4):619-628.

4. Devirgiliis C, Zalewski PD, Perozzi G, Murgia C. Zinc fluxes and zinc transporter genes in chronic diseases. Mutation Research/ Fundamental and Molecular Mechanisms of Mutagenesis. 2007;622(1-2):84-93.

5. Tapiero H, Tew KD. Trace elements in human physiology and pathology: zinc and metallothioneins. Biomedicine \& Pharmacotherapy. 2003;57(9):399-411.

6. Bowen PK, Drelich J, Goldman J. Zinc Exhibits Ideal Physiological Corrosion Behavior for Bioabsorbable Stents. Advanced Materials. 2013;25(18):2577-2582.

7. Staiger MP, Pietak AM, Huadmai J, Dias G. Magnesium and its alloys as orthopedic biomaterials: A review. Biomaterials. 2006;27(9):1728-1734.

8. Xiao C, Wang L, Ren Y, Sun S, Zhang E, Yan C, et al. Indirectly extruded biodegradable $\mathrm{Zn}-0.05 \mathrm{wt} \% \mathrm{Mg}$ alloy with improved strength and ductility: In vitro and in vivo studies. Journal of Materials Science \& Technology. 2018;34(9):1618-1627.

9. Liu HW, Luo CP, Liu JW. Effects of yttrium and mixed rare earth on microstructure and properties of magnesium, aluminum and zinc alloys. Special Casting and Non-Ferrous Alloys. 2003;(5):14-17. (in Chinese).

10. Su ZJ, Liu CM, Wang YC, Shu X. Effect of Y content on microstructure and mechanical properties of $\mathrm{Mg}-2.4 \mathrm{Nd}-0.2 \mathrm{Zn}-0.4 \mathrm{Zr}$ alloys. Materials Science \& Technology. 2013;29(2):148-155.

11. Xu DK, Tang WN, Liu L, Xu YB, Han EH. Effect of Y concentration on the microstructure and mechanical properties of as-cast $\mathrm{Mg}-\mathrm{Zn}-\mathrm{Y}-\mathrm{Zr}$ alloys. Journal of Alloys \& Compounds. 2007;432(1-2):129-134.

12. Li Q, Wang Q, Wang Y, Zeng X, Ding W. Effect of Nd and $\mathrm{Y}$ addition on microstructure and mechanical properties of as-cast $\mathrm{Mg}-\mathrm{Zn}-\mathrm{Zr}$ alloy. Journal of Alloys and Compounds. 2007;427(1-2):115-123.
13. Zhao J, Zhang J, Liu W, Wu G, Zhang L. Effect of Y content on microstructure and mechanical properties of as-cast $\mathrm{Mg}-$ 8Li-3Al-2Zn alloy with duplex structure. Materials Science \& Engineering: A. 2016;650:240-247.

14. Clark JB. Transmission electron microscopy study of age hardening in a $\mathrm{Mg}-5$ wt.\% $\mathrm{Zn}$ alloy. Acta Metallurgica. 1965;13(12):1281-1289.

15. Mostaed E, Sikora-Jasinska M, Mostaed A, Loffredo S, Demir AG, Previtali B, et al. Novel Zn-based alloys for biodegradable stent applications: Design, development and in vitro degradation. Journal of the Mechanical Behavior of Biomedical Materials. 2016;60:581-602.

16. Cai ZX, Jiang HT, Tang D, Ma Z, Kang Q. Texture and stretch formability of rolled $\mathrm{Mg}-\mathrm{Zn}-\mathrm{RE}(\mathrm{Y}, \mathrm{Ce}$, and $\mathrm{Gd})$ alloys at room temperature. Rare Metals. 2013;32(5):441-447.

17. Tong LB, Li X, Zhang DP, Cheng LR, Meng J, Zhang HJ. Dynamic recrystallization and texture evolution of $\mathrm{Mg}-\mathrm{Y}-\mathrm{Zn}$ alloy during hot extrusion process. Materials Characterization. 2014;92:77-83.

18. Liu P, Jiang H, Cai Z, Kang Q, Zhang Y. The effect of Y, $\mathrm{Ce}$ and $\mathrm{Gd}$ on texture, recrystallization and mechanical property of $\mathrm{Mg}-\mathrm{Zn}$ alloys. Journal of Magnesium \& Alloys. 2016;4(3):188-196.

19. Wang LQ, Ren YP, Qin GW. Advances in biodegradable zincbased alloys. Rare Metals. 2017;41(5):571-578. (in Chinese)

20. Erinc M, Sillekens WH, Mannens RGTM, Werkhoven RJ. Applicability of existing magnesium alloys as biomedical implant materials. In: Magnesium Technology 2009; 2009 Feb 15-19; San Francisco, CA, USA. p. 209-214.

21. Liu JH, Song YG, Shan DY, et al. Effects of twin crystals on corrosion mechanism of rare earth magnesium alloy EW75. National Academic Exchange Meeting on Corrosion Electrochemistry and Test Methods. 2016;757(1):356-363. (in Chinese)

22. Song Y, Liu ZP, Jia XD. Research progress on toxicological safety of rare earth elements. Journal of Health Research. 2013;42(5):885-892. (in Chinese). 